University of Nebraska - Lincoln

DigitalCommons@University of Nebraska - Lincoln

USDA Forest Service / UNL Faculty Publications U.S. Department of Agriculture: Forest Service -National Agroforestry Center

2004

\title{
Trends in fire patterns in a southern African savanna under alternative land use practices
}

Andrew T. Hudak

Rocky Mountain Research Station, ahudak@fs.fed.us

Dean H.K. Fairbanks

University of Cape Town, deanf@botzoo.uct.ac.za

Bruce H. Brockett

North West Parks and Tourism Board, bbrockett@nwpg.org.za

Follow this and additional works at: https://digitalcommons.unl.edu/usdafsfacpub

Hudak, Andrew T.; Fairbanks, Dean H.K.; and Brockett, Bruce H., "Trends in fire patterns in a southern African savanna under alternative land use practices" (2004). USDA Forest Service / UNL Faculty Publications. 173.

https://digitalcommons.unl.edu/usdafsfacpub/173

This Article is brought to you for free and open access by the U.S. Department of Agriculture: Forest Service -National Agroforestry Center at DigitalCommons@University of Nebraska - Lincoln. It has been accepted for inclusion in USDA Forest Service / UNL Faculty Publications by an authorized administrator of DigitalCommons@University of Nebraska - Lincoln. 


\title{
Trends in fire patterns in a southern African savanna under alternative land use practices
}

\author{
Andrew T. Hudak ${ }^{a, *}$, Dean H.K. Fairbanks ${ }^{b, 1}$, Bruce H. Brockett ${ }^{c, 2}$ \\ ${ }^{a}$ USFS Rocky Mountain Research Station, 1221 S. Main St., Moscow, ID 83843, USA \\ ${ }^{\mathrm{b}}$ Percy Fitzpatrick Institute, University of Cape Town, Rondebosch 7701, South Africa \\ ${ }^{\mathrm{c}}$ North West Parks and Tourism Board, P.O. Box 1201, Mogwase 0314, South Africa
}

\begin{abstract}
Climate, topography, vegetation and land use interact to influence fire regimes. Variable fire regimes may promote landscape heterogeneity, diversification in vegetation pattern and biotic diversity. The objective was to compare effects of alternative land use practices on landscape heterogeneity. Patch characteristics of fire scars were measured from 21 annual burn maps produced from 1972 to 2001 Landsat imagery. Trends in fire patterns under alternative land use practices were compared across a 250,000 ha savanna in southern Africa partitioned into three land use zones. Zone 1, Madikwe Game Reserve (MGR), has had mostly prescribed fires since 1993. Zone 2, cattle farms near MGR in South Africa (SAF), has experienced occasional fires. Zone 3, communal grazing lands in neighboring Botswana (BOT), has had the fewest fires. Cattle ranching was the predominant land use throughout the study area until 1992, when land use switched to conservation and eco-tourism in MGR. Sixteen landscape metrics were applied to this data set to uncover trends in the patch characteristics of the fire scars. A principal components analysis (PCA) reduced the dimensionality of the results so trends in the 10 most important size, shape, and proximity metrics could be better interpreted. The PCA results showed that more burning over time in MGR, and to a lesser extent in SAF, increased patch size, size variability, shape complexity and proximity, while fire exclusion in BOT produced no change or decreasing trends. We tested for significant differences in these metrics between the three land use zones and between two periods, 1972-1992 and 1993-2001. Most patch characteristics in MGR and SAF differed significantly from those in BOT, especially during the latter period, while between MGR and SAF they did not. Patch area, shape complexity and core area increased significantly between periods in MGR, while patch size, size variability and core area increased significantly between periods in SAF. In BOT, no patch characteristics changed significantly between periods. Within the time span analyzed for the study area, we conclude that increased fire occurrence promoted landscape heterogeneity while fire exclusion did not. Published by Elsevier B.V.
\end{abstract}

Keywords: Botswana; Fire exclusion; Fire management; Landsat; Landscape heterogeneity; Landscape metric; Patch characteristic; Prescribed fire; Principal components analysis; South Africa

\section{Introduction}

\footnotetext{
* Corresponding author. Tel.: +1-208-883-2327; fax: $+1-208-883-2318$.

E-mail addresses: ahudak@fs.fed.us (A.T. Hudak), deanf@botzoo.uct.ac.za (D.H.K. Fairbanks), bbrockett@nwpg.org.za (B.H. Brockett).

${ }^{1}$ Tel.: +27-21-650-3634; fax: +27-21-650-3295

2 Tel.: +27-14-555-5351; fax: +27-14-555-5525.
}

\subsection{Background}

Fire has tremendous influence on vegetation pattern in savannas and is the major determinant of savanna vegetation structure and floristic composition (Scholes and Walker, 1993). Researchers in southern 
Africa have amassed a large body of information on fire effects on savanna vegetation (e.g. Phillips, 1930; Acocks, 1953; Trapnell, 1959; Trollope and Tainton, 1986; Bond, 1997). Savanna vegetation dynamics are inherently unstable (Norton-Griffiths, 1979; McNaughton, 1984; Trollope, 1984; Westoby et al., 1989) and respond to periodic yet spatially and temporally unpredictable climate, fire, grazing, and browsing events (Bond and van Wilgen, 1996).

Fires are limited by fine fuel availability, which is in turn dependent on soil moisture and nutrient availability (Rutherford, 1980; Scholes and Walker, 1993). Flammability varies among plant communities, and fuel breaks due to roads and topography affect fire spread (Whelan, 1995) and size (Rupp et al., 2000b) across the landscape mosaic. Weather, topography and fire history interact in complex ways to modify fuel characteristics (notably fuel biomass and dead-to-live ratio) across the landscape (Christensen, 1981; Whelan, 1995; Morgan et al., 2001). Fires in southern African savannas typically occur late in the dry season (August-November), prior to the first seasonal rains (van Wilgen et al., 1990, 2000; Brockett et al., 2001).

The frequency at which a landscape burns depends on many factors, as well as their interactions. Shifts in fire frequency lead to changes in vegetation structure and composition, which in turn modify the intensity of subsequent fires (Kilgore, 1981).

Fuels after recent fires often have insufficient dead fuel to sustain even low-medium intensity fires. Fires are also limited by ignitions, which depend on land use, lightning strikes, fuel condition and other factors. Fire size is nested hierarchically under other fire regime descriptors (e.g. frequency, intensity and seasonality) and physical factors (Fig. 1). Fires often are irregular in size and shape and may promote heterogeneity in vertical and horizontal vegetation structure (Forman, 1995).

Landsat imagery, now available for over 30 years, can help provide useful data for mapping fire scars (Richards, 1984; Hudak et al., 1998; Patterson and Yool, 1998) and fire history (Russell-Smith et al., 1997; Hudak and Brockett, 2004). Landscape metrics

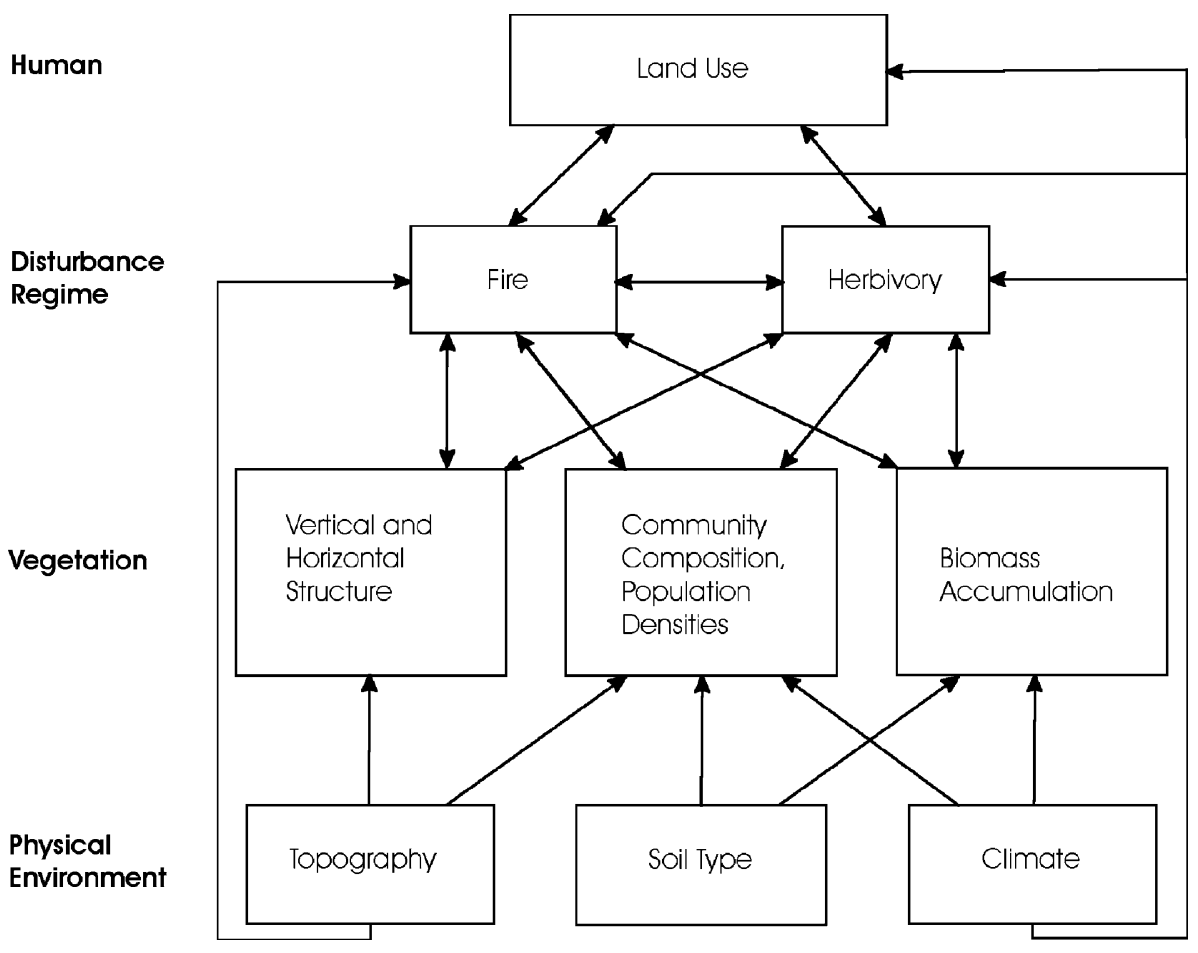

Fig. 1. Conceptual diagram illustrating interactions between physical environment, vegetation, disturbance and land use (modified from Riba and Terradas, 1987; Whelan, 1995). 
may be applied to fire scar maps derived from Landsat imagery. Landscape metrics are fundamental ecological assessment tools and offer promise to land managers because they can measure the pattern of landscape elements across space and over time (Leitao and Ahern, 2002). There are literally hundreds of metrics; therefore, it is advisable to choose suitable metrics based on previous studies and reviews (Riitters et al., 1995; McGarigal and McComb, 1995; Gustafson, 1998). Landscape metrics have been used to show the effects of fire suppression on landscape structure (Baker, 1992) and to explore if reinstating a natural fire regime may restore landscape structure after decades of fire suppression (Baker, 1994).

Landscape metrics were used to determine trends in fire patterns in a semi-arid savanna in southern Africa, using a database of annual burn maps produced from 1972 to 2001 Landsat imagery. The study area features different fire regimes with variability in space and time, due in large part to differing land use. The objective was to compare effects of alternative land use practices on landscape heterogeneity.

\subsection{Justification}

A fire history can serve as a useful database for land managers (Russell-Smith et al., 1997; van Wilgen et al., 2000; Hudak and Brockett, 2004). Provided the interpretation of burned and unburned areas is sufficiently accurate, Landsat data are suitable for determining between-fire intervals (Gill et al., 2000), patch characteristics (Turner et al., 1994; Haydon et al., 2000), fire severity (White et al., 1996; Hudak et al., 1998) and other aspects of fire regime. There is increasing interest in using landscape-level research for managing wildlands and restoring natural disturbance regimes in fire-suppressed landscapes (Baker, 1994). Studies have shown landscape metrics can be used effectively to assess fire pattern and landscape heterogeneity (Turner et al., 1994; Henry and Yool, 2002; Keane et al., 2002).

Based on procedures from McGarigal and Marks (1995) for assessing patch characteristics, landscape metrics were applied to annual burn maps produced by Hudak and Brockett (2004). Implicit throughout this study is that fire pattern is closely related to vegetation pattern; i.e., one should observe greater fire patch heterogeneity where greater vegetation hetero- geneity exists. Since vegetation heterogeneity was not measured directly in this study, the more general term landscape heterogeneity (Turner et al., 1994) was used instead. This analysis tested two hypotheses:

1. Landscape heterogeneity is a function of fire occurrence in semi-arid, southern African savanna.

2. Fire occurrence is influenced primarily by land use practice (e.g. prescribed fires or fire exclusion) in semi-arid, southern African savanna.

\section{Methods}

\subsection{Study area}

The 250,000 ha area of interest in southern Africa straddles the Botswana (BOT)-South Africa border just southeast of Gaborone, Botswana's capital (Fig. 2). The study area was partitioned into three land use zones. Zone 1 in South Africa is Madikwe Game Reserve (MGR), where many fires since 1992 have been prescribed. Zone 2 consists of South African farms (SAF) outside of MGR in portions of Lehurutshe, Marico, Madikwe and Thabazimbi Districts, where farmers occasionally prescribe fires. Zone 3 in BOT is primarily a communal grazing area in Kgatleng and South East Districts, where fires are discouraged.

Most of the study area has been or is currently used as livestock range (Table 1). Grazing is most intensive in BOT, which reduces vegetation biomass and limits fuel for fires. There is limited dryland cropping in BOT and some irrigation cropping in SAF near the Marico River along MGRs eastern border. MGR was established in 1991 by the government of the former Apartheid-era tribal homeland of Bophuthatswana, after a specially-commissioned land survey (Setplan, 1991) concluded that a game reserve would be more profitable than the existing cattle farms, which had become severely bush encroached after decades of heavy grazing (Hudak, 1999b). Managers in MGR began applying prescribed fires in 1992, and since 1993 fires have been applied or wildfires managed with the objectives of controlling bush encroachment and hence enhancing game visibility for tourists.

Climate is semi-arid, with $95 \%$ of annual rainfall occurring between October and April. Annual rainfall averaged $520 \mathrm{~mm}$ across 35 area stations from 1909 to 


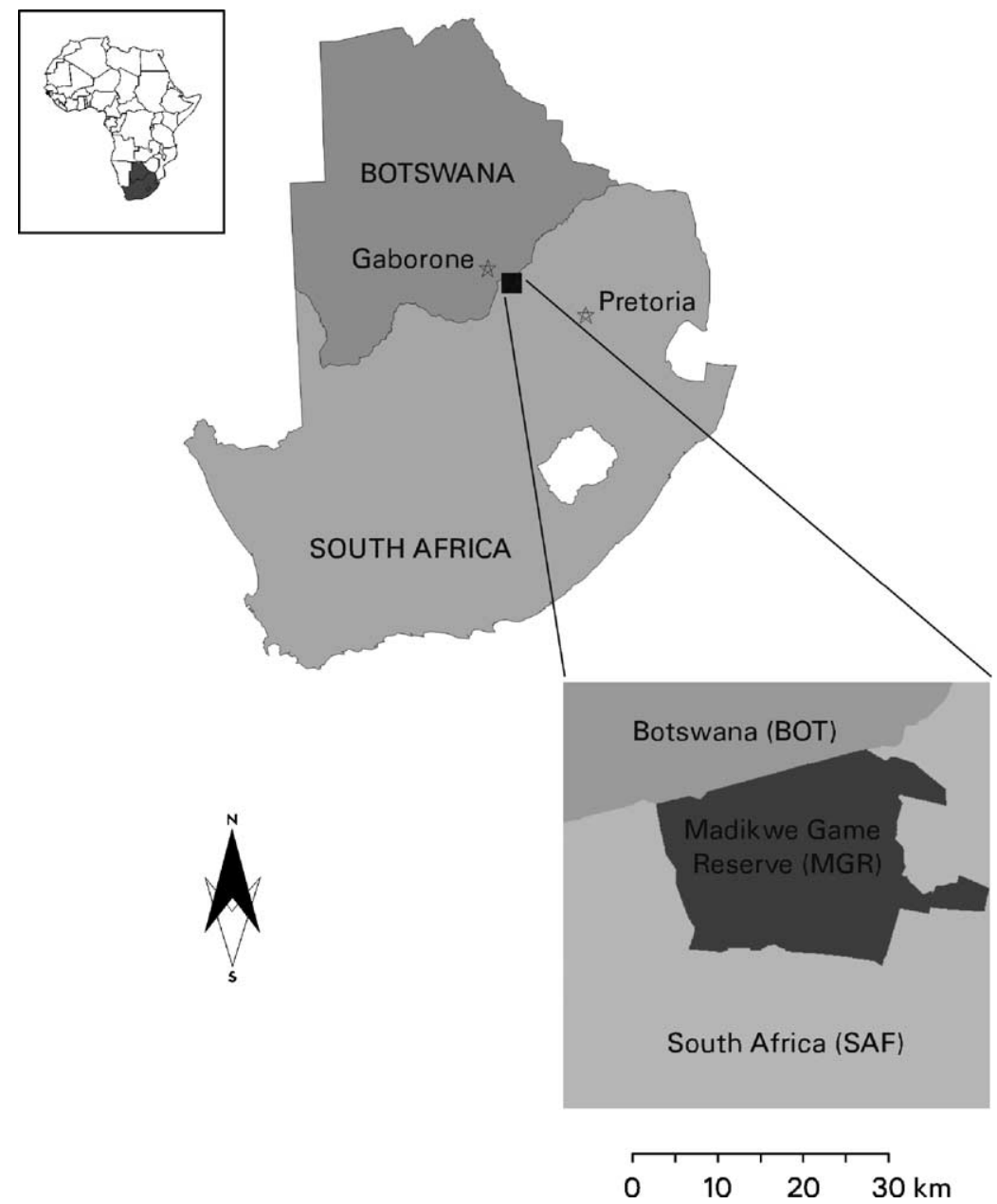

Fig. 2. Location of study area, with three land use zones indicated.

2002, with a standard deviation of $171 \mathrm{~mm}$. Elevation ranges from 872 to $1474 \mathrm{~m}$, yet the landscape is generally flat except for roughly parallel ridges of rocky terrain along MGR's southern boundary and through its center. Soils are heterogeneous across the study area, ranging from heavy clays ( $46 \%$ clay) to sandy loams ( $73 \%$ sand), and soil texture is a major determinant of vegetation structure and plant community composition

Table 1

Descriptions of the three land use zones compared

\begin{tabular}{|c|c|c|c|c|}
\hline Zone & Code & Description & Land use & Fire management \\
\hline 1 & MGR & Madikwe Game Reserve & $\begin{array}{l}\text { Stocked with cattle until circa } 1988 \text {; stocked } \\
\text { with a range of native ungulates including } \\
\text { elephant and white rhino since } 1992\end{array}$ & $\begin{array}{l}\text { Fire management since } \\
1992\end{array}$ \\
\hline 2 & SAF & $\begin{array}{l}\text { South African farms W, S } \\
\text { and E of MGR }\end{array}$ & Stocked with cattle & $\begin{array}{l}\text { Some prescribed fires } \\
\text { otherwise mostly wildfires }\end{array}$ \\
\hline 3 & BOT & $\begin{array}{l}\text { Communal grazing land } \\
\text { in Botswana, } \mathrm{N} \text { of MGR }\end{array}$ & Stocked with cattle, goats, and some sheep & Fire exclusion \\
\hline
\end{tabular}


(Hudak et al., 2003). Important woody species include: Dichrostachys cinerea subsp. africana, Acacia tortilis, A. nilotica, A. erubescens, A. mellifera, A. robusta, A. caffra, A. karroo, Combretum apiculatum, C. imberbe, Grewia spp. and Sclerocarya birrea (Hudak, 1999a).

\subsection{Fire scar mapping}

Fire scar extents were mapped annually from 1972 to 2001 , however, there were several years when Landsat images were not available (1974, 1976-1978, 1981-1985). Most of the images obtained were captured late in the dry season, or soon after the majority of fires generally occur, to maximize mapping accuracy. The spectral signatures of burned areas could be better distinguished after principal components analysis (PCA) (Richards, 1984; Singh and Harrison, 1985; Fung and LeDrew, 1987) than in the raw data. Burned areas were subsequently separated from unburned areas with a supervised classification (parallelepiped) of the principal components (PCs). Mapping accuracy was better than $90 \%$, matching the mapping accuracy of the most similar prior fire history mapping study, conducted in Australia (Russell-Smith et al., 1997). Hudak and Brockett (2004) provide full details on the image processing and validation methods used.

Fire scar classifications of the 34 images were grouped by year into 21 annual burn maps (1972-1973, 1975, 1979-1980, 1986-2001) in Arc/Info GRID (ESRI, Redlands, CA). The original burn maps varied in extent from $50 \mathrm{~km} \times 50 \mathrm{~km}$ to $60 \mathrm{~km} \times 60 \mathrm{~km}$ according to the extent of the source imagery. This study of patch dynamics required that comparisons be over a common spatial extent, so the $50 \mathrm{~km} \times 50 \mathrm{~km}$ central portion of each map was extracted. The maps had a grid cell resolution of $1 \mathrm{ha}$, which is considered appropriate for the development of pattern metrics over a large area (O'Neill et al., 1996). Annual burn maps were then partitioned into two periods of interest, 1972-1992 or 1993-2001, to test the hypotheses. Cumulative maps of fire scars for both periods also were produced, by summing the appropriate annual burn maps and then applying a median filter.

\subsection{Rainfall analysis}

Monthly rainfall data were obtained for 35 stations situated either inside the study area $(N=30)$ or $<16 \mathrm{~km}$ outside the edge $(N=5)$. Monthly values were summed into seasonal totals for each station, with "seasonal" defined as the 12-month period beginning 1 July of the previous year. (Seasonal rainfall is more ecologically meaningful than annual (January-December) rainfall in this region because it encompasses the entire rainy season preceding the burning season.) Years with missing monthly values were omitted so as not to bias the sums. Finally, stations having data within the 1972-2001 period of interest were extracted, yielding 27 of the original 35, with 7-16 stations supplying seasonal rainfall data for any given year. The rainfall statistical analysis was performed in $R$.

Table 2

Sixteen landscape class metrics included in the analysis, grouped by type ${ }^{\mathrm{a}}$

\begin{tabular}{|c|c|}
\hline $\begin{array}{l}\text { Metric group and } \\
\text { abbreviation }^{\mathrm{b}}\end{array}$ & Metric name \\
\hline \multicolumn{2}{|l|}{ Area metrics } \\
\hline $\mathrm{CA}$ & Class area \\
\hline LPI & Large patch index \\
\hline \multicolumn{2}{|c|}{ Patch density and size metrics } \\
\hline NP & Number of patches \\
\hline MPS & Mean patch size \\
\hline PSSD & Patch size standard deviation \\
\hline \multicolumn{2}{|l|}{ Edge metrics } \\
\hline $\mathrm{TE}$ & Total edge \\
\hline \multicolumn{2}{|l|}{ Shape metrics } \\
\hline MSI & Mean shape index \\
\hline AWMSI & $\begin{array}{l}\text { Area weighted mean shape } \\
\text { index }\end{array}$ \\
\hline MPFD & Mean patch fractal dimension \\
\hline AWMPFD & $\begin{array}{l}\text { Area weighted mean patch } \\
\text { fractal dimension }\end{array}$ \\
\hline LSI & Large shape index \\
\hline \multicolumn{2}{|c|}{ Interspersion metrics } \\
\hline MPI & Mean proximity index \\
\hline \multicolumn{2}{|l|}{ Core area metrics } \\
\hline $\mathrm{TCA}$ & Total core area \\
\hline MCA & Mean core area \\
\hline CASD & Core area standard deviation \\
\hline TCAI & Total core area index \\
\hline
\end{tabular}




\subsection{Landscape metrics}

A set of 16 landscape metrics was employed to uncover temporal trends in the spatial characteristics of the fire scar patches mapped from 1972 to 2001. These metrics can be generalized into six classes according to patch characteristic (Table 2). Each map was processed (FRAGSTATS; McGarigal and Marks, 1995) to compute the spatial configuration of the patches for each year. The MGR boundary and international border were the zonal boundaries considered for the purpose of calculating all the metrics. (Since 1994, MGR has undergone several small expansions along its eastern border. Because the added area (926 ha) is small relative to the extent of the study area (250,000 ha), we ignored this complication in the analysis and used the current MGR border to define Zone 1, as illustrated in Fig. 2.) The true size of peripheral patches decreases due to the constraint imposed by an artificial boundary. Since there is nothing simple that can be done about this, conclusions drawn from the analyzed data must be appropriately tempered. Several core area indices were calculated based on a specified edge width, which for the purpose of this study was defined as a $100 \mathrm{~m}$ wide buffer along the perimeter of each fire scar patch. This was done to reduce the number of small, spurious fire scar patches that might represent misclassifications.

\subsection{Statistical analyses}

Whether through theoretical considerations or a more objective statistical analysis, landscape metrics need to be examined for independence, as they tend to covary (McGarigal and McComb, 1995; Riitters et al., 1995; Tinker et al., 1998). While the aforementioned

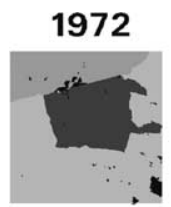

1979

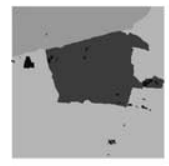

1988

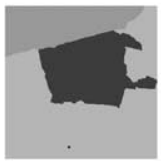

1993

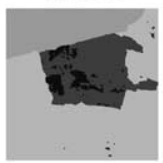

1998

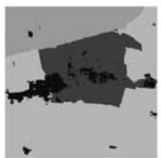

1973

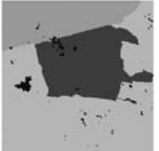

1980

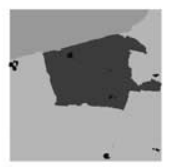

1989

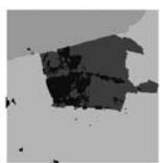

1994

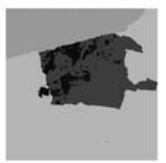

1999

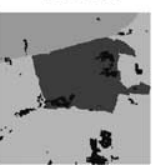

1974

1975

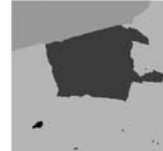

1986

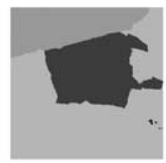

1991

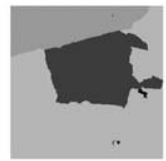

1996
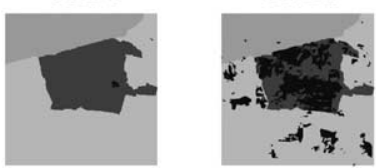

1997

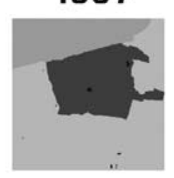

Fire Scar
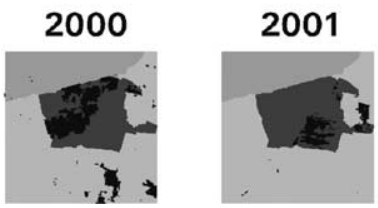

MGR (Zone 1)

SAF (Zone 2)

BOT (Zone 3)

Fig. 3. Annual burn maps (1972-2001) from Hudak and Brockett (2004). Each map extent is $50 \mathrm{~km} \times 50 \mathrm{~km}$, and the spatial resolution is 1 ha. 
authors statistically determined a reduced set of metrics for use in North American landscapes, there is no guarantee that the same metrics extend to other ecosystems and regions of the world. Therefore, fol- lowing methods outlined in Riitters et al. (1995) and Tinker et al. (1998), the dimensionality of the patch metrics calculated for each land use zone was reduced using PCA with a varimax rotation to group metrics

(a) 1972-1992 (Period 1)

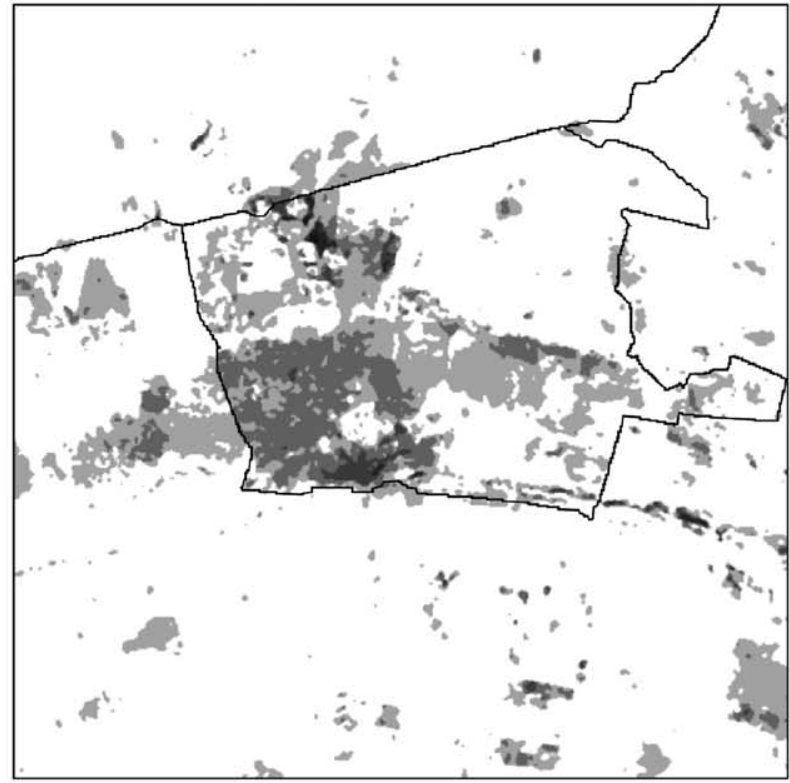

\begin{tabular}{|rrr|}
\hline $\begin{array}{l}\text { Number } \\
\text { of Fires }\end{array}$ & $\begin{array}{r}\text { Area } \\
\text { (ha) }\end{array}$ \\
5 & $\square$ & 38 \\
4 & $\square$ & 295 \\
3 & $\square$ & 1283 \\
2 & $\square$ & 10774 \\
1 & $\square$ & 30197 \\
0 & $\square$ & 207413 \\
\hline
\end{tabular}

(b) 1993-2001 (Period 2)
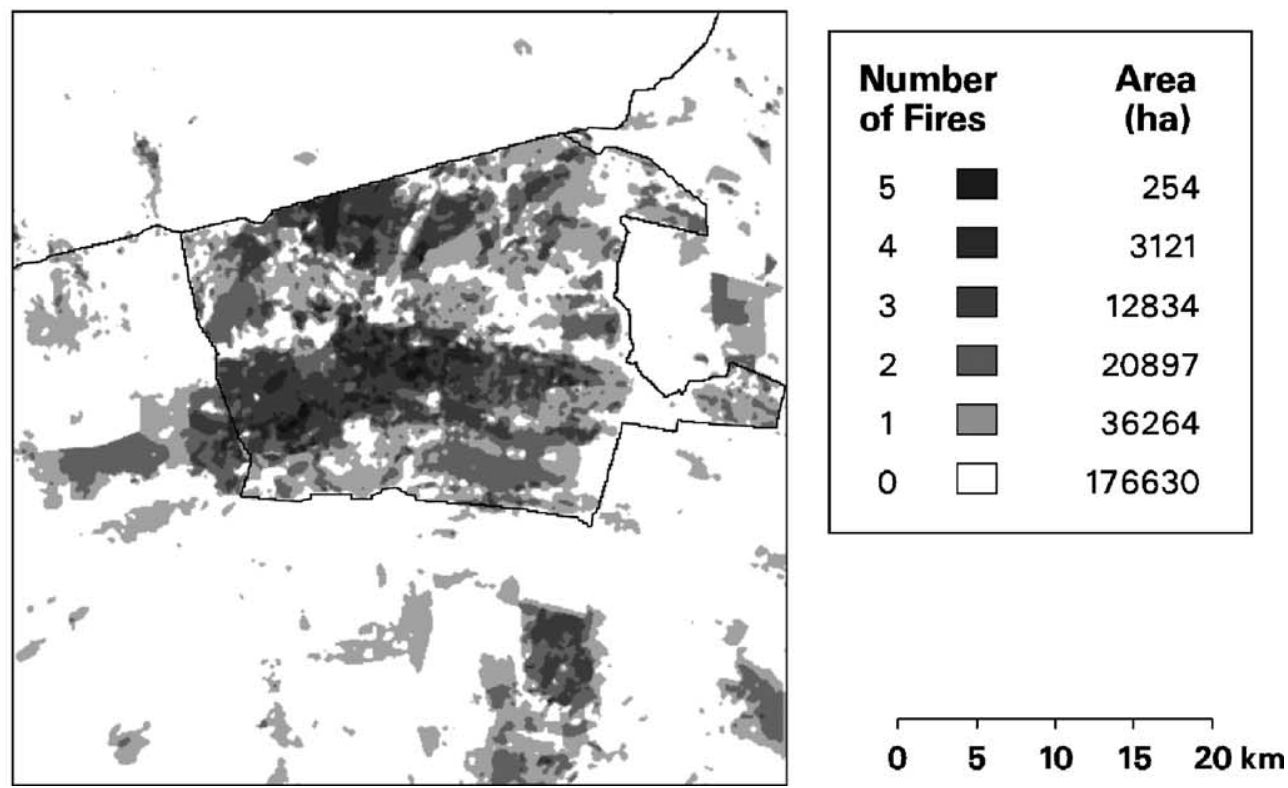

Fig. 4. Maps of fire scars documented for periods: (a) 1972-1992 and (b) 1993-2001. 
into uncorrelated components that explained most of the variation in the original data sets. A varimax rotation allows for a better fit of the PC axes with the scores, and thus better interpretability of the axes (Legendre and Legendre, 1998). The number of factors to interpret was determined using the broken stick method (Legendre and Legendre, 1998). This test usually recognizes the first two or three PCs as meaningful and corresponds to empirical studies confirmed by Jackson (1993). Landscape metrics with factor loadings $>0.7$ were considered important. The resulting factors and their scores represented interpretable, independent measurements of variation within each data set that could be used to describe the spatial and temporal trends found within each land use zone for the length of recorded data.

One- and two-way analysis of variance (ANOVA) operations were also performed on the patch metrics to determine significant differences between land use zones and periods. The procedures were conducted in an objective effort to define a subset of significant metrics useful for management and monitoring. Significant variables $(\alpha=0.05)$ are denoted in the results. Statistical calculations were performed in Systat (SPSS, Chicago, IL).

\section{Results}

\subsection{Burn maps}

Annual burn maps over the two time periods of interest reveal increased fire frequency in Period 2 relative to the longer Period 1 (Fig. 3). The increase in MGR is not accompanied by a comparable increase in SAF, and fire exclusion continued in BOT during both periods (Fig. 4). Examination of the burned area trends for all three land use zones, in conjunction with the mean seasonal rainfall trend across the study area, illustrates poor correspondence between these variables within the spatial and temporal limits of the analysis (Fig. 5).

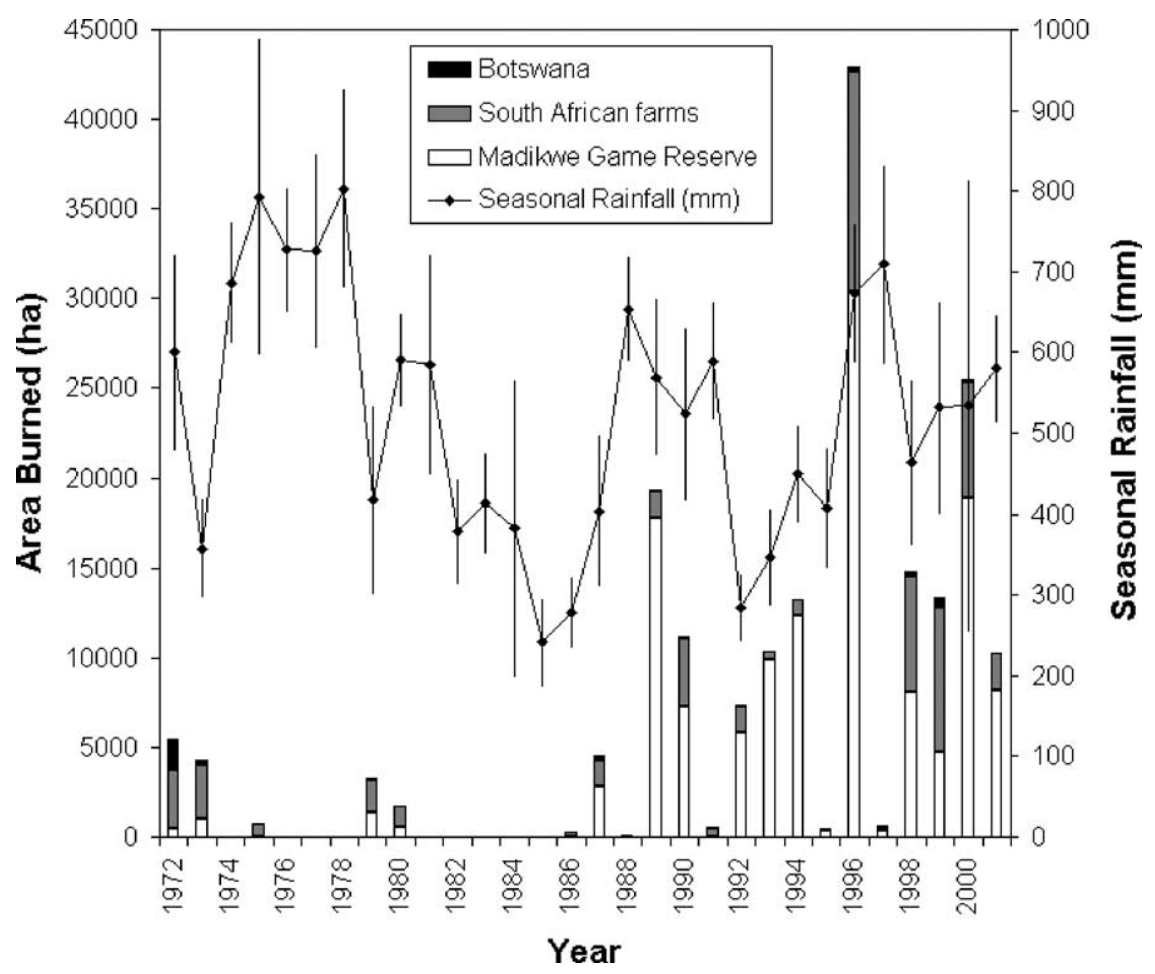

Fig. 5. Total hectares burned annually in three land use zones, plotted with mean ( \pm standard deviation) seasonal rainfall, 1972-2001. Total area of each land use zone: MGR $=60,452$ ha; $\mathrm{SAF}=140,202$ ha; BOT $=49,346$ ha. 


\subsection{Rainfall analysis}

Seasonal rainfall variation between years (coefficient of variation $=30.0 \%$ ) was considerably greater than between stations (coefficient of variation = $13.4 \%)$. Visually, seasonal rainfall trends looked similar between stations, with large deviations from the general trend confined to individual stations and years. Student's $t$-tests comparing individual stations in separate land use zones and having at least 16 years of data between 1972 and 2001 yielded only insignificant differences $(P>0.1)$. Stations located within the same land use zone were then grouped; subsequent $t$-test comparisons between MGR ( $N=$ $8)$, SAF $(N=15)$ and BOT $(N=4)$ were all insignificant. Similar comparisons between land use zones within each period were only insignificant as well. Therefore, the data were pooled across all stations to produce a mean seasonal rainfall trend representative of the entire study area, to compare visually against the burn area trend (Fig. 5). A final $t$-test across all 27 stations revealed no significant difference in seasonal rainfall between periods $(P=0.6725)$.

\subsection{Landscape metrics}

The PCA results served to identify which landscape metrics explained most of the variation in the patch data and helped to identify major trends between periods for each land use zone. PC1 was most heavily weighted by patch shape variability in MGR, patch size variability in SAF and patchiness in BOT. PC2 was most heavily weighted by shape complexity in MGR, SAF and BOT. PC3 was most heavily weighted by patchiness in MGR and SAF (Appendix A).

\subsection{Significance tests}

A two-way ANOVA comparing landscape metrics against land use zone (MGR, SAF, or BOT) and period (1972-1992 or 1993-2001) revealed significant differences between zones for 13 of the 16 metrics tested (Table 3). Differences between periods were significant for 8 of the 16 metrics tested, distributed across all metric groups. Following a pattern similar to period comparisons, 10 of the 16 significant interactions between land use zone and period were found.
Table 3

Two-way ANOVA significance levels comparing 16 landscape metrics against three land use zones (MGR, SAF, BOT) and two periods (1972-1992, 1993-2001)

\begin{tabular}{|c|c|c|c|}
\hline Landscape metric ${ }^{\mathrm{a}}$ & Zone & Period & Zone $\times$ period \\
\hline \multicolumn{4}{|l|}{$\overline{\text { Area }}$} \\
\hline $\mathrm{CA}$ & $0.0000^{* * *}$ & 0.0958 & $0.0239^{*}$ \\
\hline LPI & $0.0000^{* * *}$ & $0.0165^{*}$ & 0.0932 \\
\hline \multicolumn{4}{|l|}{ Density and size } \\
\hline NP & $0.0001^{* * *}$ & 0.3505 & 0.2820 \\
\hline MPS & $0.0000^{* * *}$ & $0.0285^{*}$ & $0.0020^{* *}$ \\
\hline PSSD & $0.0000^{* * *}$ & $0.0250^{*}$ & $0.0152^{*}$ \\
\hline \multicolumn{4}{|l|}{ Edge } \\
\hline TE & $0.0052^{* *}$ & 0.1901 & 0.0619 \\
\hline \multicolumn{4}{|l|}{ Shape } \\
\hline MSI & 0.2692 & 0.2431 & $0.0301^{*}$ \\
\hline AWMSI & $0.0146^{*}$ & 0.1940 & 0.1257 \\
\hline MPFD & 0.2966 & 0.2877 & 0.1577 \\
\hline AWMPFD & 0.3044 & 0.2495 & 0.1397 \\
\hline LSI & $0.0014^{* *}$ & $0.0388^{*}$ & $0.0400^{*}$ \\
\hline \multicolumn{4}{|l|}{ Interspersion } \\
\hline MPI & $0.0000^{* * *}$ & $0.0385^{*}$ & $0.0494^{*}$ \\
\hline \multicolumn{4}{|l|}{ Core area } \\
\hline TCA & $0.0000^{* * *}$ & 0.0656 & $0.0247^{*}$ \\
\hline MCA & $0.0000^{* * *}$ & $0.0234^{*}$ & $0.0051^{* *}$ \\
\hline CASD & $0.0000^{* * *}$ & $0.0308^{*}$ & $0.0365^{*}$ \\
\hline TCAI & $0.0000^{* * *}$ & $0.0114^{*}$ & $0.0059^{* *}$ \\
\hline
\end{tabular}

${ }^{\mathrm{a}}$ Landscape metric abbreviations are defined in Table 2.

* Significance at $P<0.05$.

** Significance at $P<0.01$.

*** Significance at $P<0.001$.

The 10 metrics showing significant zone $\times$ period interactions in Table 3 were analyzed further in a one-way ANOVA to look for significant differences between individual land use zones grouped by period (Table 4). MGR was compared to SAF and BOT for Period 1 but no significant differences were found. Since the MGR fire management program is only relevant to Period 2, MGR and SAF were grouped together as Zone 2 for Period 1. For Period 1, differences between the combined MGR-SAF and BOT were significant for 7 of the 10 metrics tested, predominantly the area and core area metrics. For Period 2, BOT differed significantly from SAF for all 10 metrics, and from MGR for 9 of the 10 metrics; MGR and SAF did not differ significantly for any metric.

The same 10 landscape metrics were analyzed in another one-way ANOVA comparing Periods 1 and 2 for each land use zone. Patch area, shape complexity 
Table 4

One-way ANOVA statistics comparing land use zones grouped by period for 10 landscape metrics with significant zone $\times$ period interactions $(\text { Table } 3)^{\mathrm{a}}$

\begin{tabular}{|c|c|c|c|c|}
\hline Landscape metric ${ }^{b}$ & Period 1 (1972-1992) & Bonferroni differences & Period 2 (1993-2001) & Bonferroni differences \\
\hline \multicolumn{5}{|l|}{ Area } \\
\hline $\mathrm{CA}$ & 0.0289 & $2 / 3^{*}$ & 0.0000 & $1 / 3^{* *}, 2 / 3^{* *}$ \\
\hline \multicolumn{5}{|l|}{ Size } \\
\hline MPS & 0.1866 & None & 0.0000 & $1 / 3^{* *}, 2 / 3^{* *}$ \\
\hline PSSD & 0.0142 & $2 / 3^{*}$ & 0.0000 & $1 / 3^{* *}, 2 / 3^{* *}$ \\
\hline \multicolumn{5}{|l|}{ Shape } \\
\hline MSI & 0.7881 & None & 0.0089 & $1 / 3^{* *}$ \\
\hline LSI & 0.1388 & None & 0.0010 & $1 / 3^{* *}, 2 / 3^{*}$ \\
\hline \multicolumn{5}{|l|}{ Interspersion } \\
\hline MPI & 0.0265 & $2 / 3^{*}$ & 0.0001 & $1 / 3^{* *}, 2 / 3^{*}$ \\
\hline \multicolumn{5}{|l|}{ Core area } \\
\hline TCA & 0.0042 & $2 / 3^{* *}$ & 0.0000 & $1 / 3^{* *}, 2 / 3^{* *}$ \\
\hline $\mathrm{MCA}$ & 0.0260 & $2 / 3^{*}$ & 0.0000 & $1 / 3^{* *}, 2 / 3^{* *}$ \\
\hline CASD & 0.0067 & $2 / 3^{* *}$ & 0.0000 & $1 / 3^{* *}, 2 / 3^{* *}$ \\
\hline TCAI & 0.0080 & $2 / 3^{* *}$ & 0.0000 & $1 / 3^{* *}, 2 / 3^{* *}$ \\
\hline
\end{tabular}

${ }^{a}$ Bonferroni corrected pairwise differences are presented to show significant differences between land use zones. Zone 1: MGR; Zone 2: SAF; Zone 3: BOT. MGR and SAF were grouped together as Zone 2 for Period 1 because the land use practices then were the same.

${ }^{\mathrm{b}}$ Landscape metric abbreviations are defined in Table 2.

* Significance at $P<0.05$.

** Significance at $P<0.01$.

\section{Table 5}

One-way ANOVA significance levels comparing periods grouped by land use zone for 10 landscape metrics with significant zone $\times$ period interactions (Table 3)

\begin{tabular}{llll}
\hline $\begin{array}{l}\text { Landscape } \\
\text { metric }^{\mathrm{a}}\end{array}$ & $\begin{array}{l}\text { Zone 1 } \\
(\mathrm{MGR})\end{array}$ & $\begin{array}{l}\text { Zone 2 } \\
(\mathrm{SAF})\end{array}$ & $\begin{array}{l}\text { Zone 3 } \\
(\mathrm{BOT})\end{array}$ \\
\hline $\begin{array}{l}\text { Area } \\
\text { CA }\end{array}$ & $0.0366^{*}$ & 0.0672 & 0.6013 \\
Size & & & \\
MPS & 0.0573 & $0.0252^{*}$ & 0.2750 \\
PSSD & 0.1253 & $0.0432^{*}$ & 0.6061 \\
Shape & & & \\
MSI & $0.0408^{*}$ & 0.7879 & 0.4485 \\
LSI & $0.0262^{*}$ & 0.3408 & 0.7761 \\
Interspersion & & & \\
MPI & 0.2770 & 0.4189 & 0.9101 \\
Core area & & & \\
TCA & $0.0395^{*}$ & $0.0363^{*}$ & 0.5571 \\
MCA & $0.0429^{*}$ & $0.0199^{*}$ & 0.4894 \\
CASD & 0.1004 & $0.0365^{*}$ & 0.6572 \\
TCAI & $0.0028^{* *}$ & 0.1641 & 0.5591 \\
\hline
\end{tabular}

${ }^{\text {a }}$ Landscape metric abbreviations are defined in Table 2.

* Significance at $P<0.05$.

** Significance at $P<0.01$. and core area metrics increased significantly in MGR, while patch size, size variability and core area metrics increased significantly in SAF. No patch metrics changed significantly in BOT (Table 5).

Box plots of five landscape metrics representing various patch characteristics illustrate that, between Periods 1 and 2, total class area, mean core area, mean patch size, patch size standard deviation, mean patch shape, and mean patch proximity exhibited the same general pattern: increases in MGR, smaller increases in SAF, and no change or decreases in BOT (Fig. 6).

\section{Discussion}

\subsection{Burn maps}

Substantial fire activity occurred in Zone 1 in 1989 and 1990 (Figs. 3 and 5), which is interesting because these fires predate the proclamation of MGR, their coverage is extensive, and their perimeter closely corresponds to the future boundary of MGR (Fig. 3). A plausible explanation is that in 1988, the former South African government purchased the land for fair market value from the resident South African farmers and 


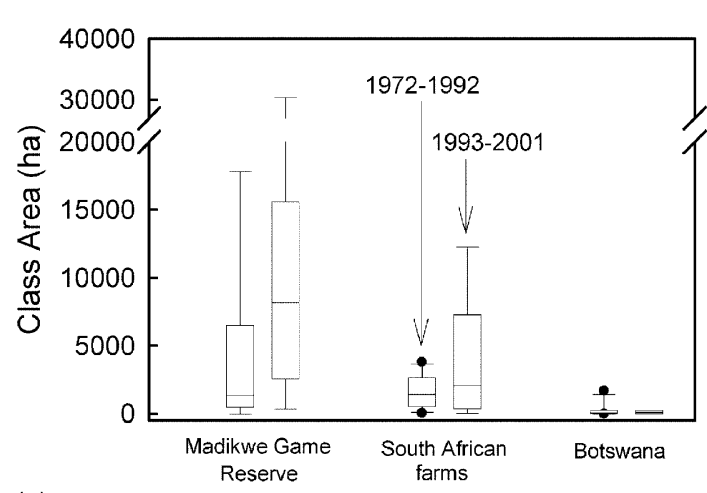

(a)

Land Use Zone

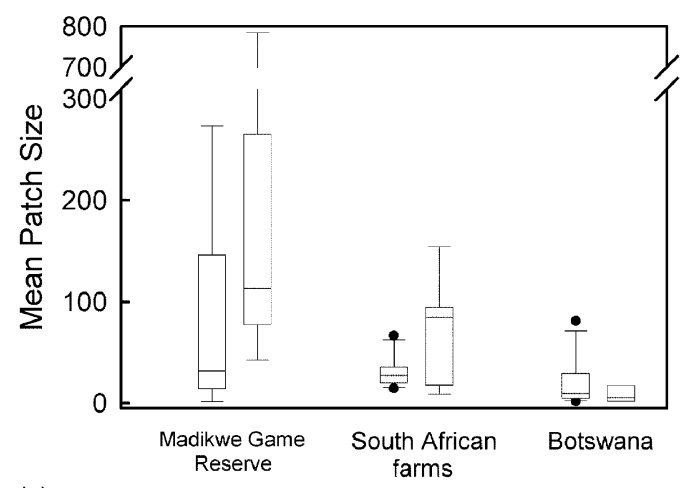

(c)

Land Use Zone

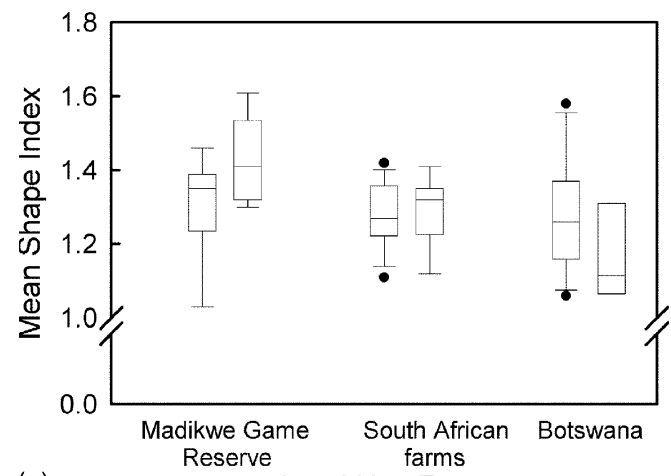

(e)

Land Use Zone

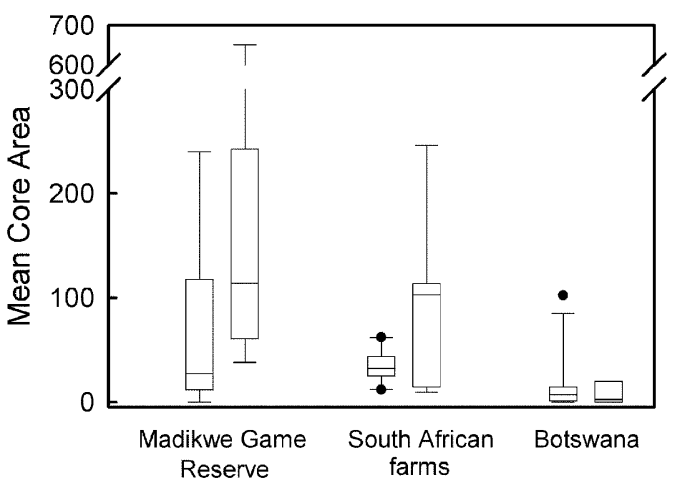

(b)
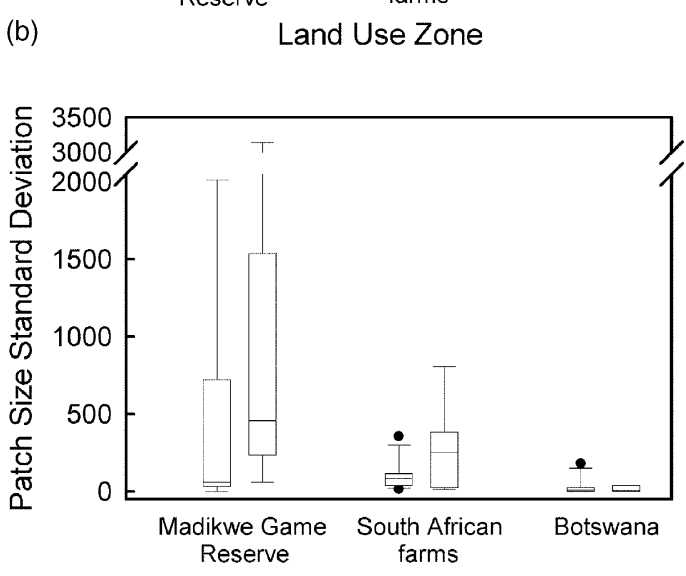

(d)

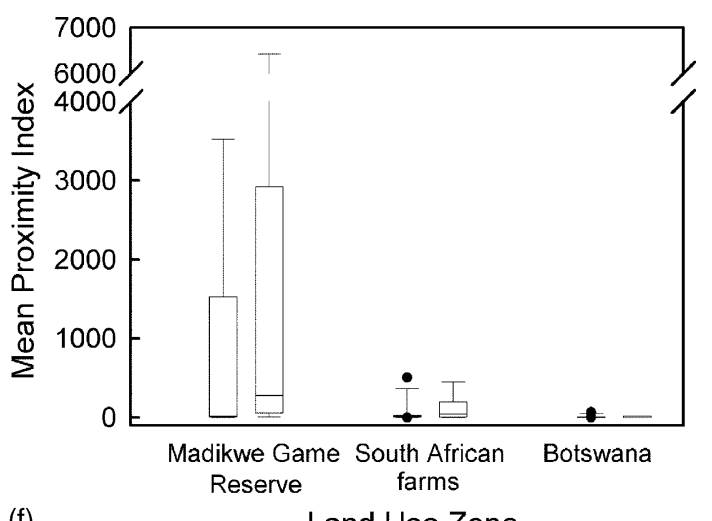

(f)

Land Use Zone

Fig. 6. Box plot pairs illustrating differences between Periods 1 (left) and 2 (right) in landscape metrics: (a) CA, (b) MCA, (c) MPS, (d) PSSD, (e) MSI and (f) MPI for each land use zone. Landscape metric abbreviations are defined in Table 2.

transferred ownership to Bophuthatswana, the largest of the quasi-independent, black homeland states established under Apartheid (Hudak, 1999b). These lands were unstocked with cattle from 1989 until 1992, when restocking of large mammals commenced in MGR (Table 1). Severe frost events during a particularly cold winter in 1987 may have top-killed up to $30 \%$ of some woody species (D. cinerea, A. nilotica and A. 
robusta) (Smit, 1990). Rainfall in 1988 and 1989 was above average (Fig. 5), which would have increased fine fuel loads in the subsequent 1989 and 1990 fire seasons. All of the above circumstances could have contributed to the extensive 1989 and 1990 fires.

Since 1993, most of the area burned in MGR has been from prescribed fires (1993, 1994, 1996, 1998-2001). Lightning caused most of the burning in MGR in 1992 and ignited small fires in 1995, 1997 and 1998. Since SAF and BOT lack formal fire management programs, most fires outside of MGR may be attributed to accidental ignitions, arson or lightning strikes. Hudak (1999b) interviewed SAF farmers in 1996 and learned that on occasion they ignite fires.

\subsection{Landscape metrics}

The 16 landscape metrics initially tested (Table 2) captured a range of patch characteristics, and the subsequent PCAs worked well for identifying the patch characteristics of import while also reducing the dimensions of the data set to a reasonable level (Appendix A). This approach enabled a more thorough and objective determination of the landscape metrics of import (Table 3), which would be unapparent from a simple visual evaluation of the annual burn maps.

The PCA results (Appendix A) provide information about the trends in correlations of the metrics. Since PCA most heavily weights the major axis (PC1), applying the varimax rotation made the minor axes (PC2 and PC3) more interpretable. The subsequent ANOVA applied to these metrics indicated which patch characteristics showed significant trends and thus deserve the attention of managers. While several individual metrics showed significant trends (Tables 3-5), many were highly correlated (Appendix A). For the sake of interpretation, we recommend not placing undue emphasis on any particular metric or the patch characteristic it indicates. Instead, it is prudent to take a more conservative approach by considering significant trends in several metrics across different groups as indicative of a general increase (or decrease) in landscape heterogeneity.

\subsection{Fire and landscape heterogeneity}

Increases in patch size, shape and proximity indices in MGR between Periods 1 and 2 appear to be due to more fires in Period 2, while no change or decreases in these same indices in BOT are associated with fire exclusion throughout the data record (Fig. 6). These results support the first hypothesis that landscape heterogeneity is a function of fire occurrence, at least within the spatial extent and time interval of this study. Where burning increased the most (MGR), landscape heterogeneity also increased the most. Where burning increased by a lesser amount (SAF), smaller increases in landscape heterogeneity were observed. Where fire exclusion persisted (BOT), landscape heterogeneity did not change significantly. While increased burning was observed to only increase landscape heterogeneity, too much burning could conceivably decrease it, just as too little.

The relative lack of significant differences in patch characteristics between MGR and SAF, compared to the differences between MGR and BOT, or SAF and BOT (Table 4), suggests that landscape heterogeneity in SAF is more similar to that in MGR than BOT. This is not surprising since MGR and SAF were managed similarly during the longer of the two periods (Period 1, 1972-1992), and probably many years before 1972 . Yet SAF tended to have the highest index values in Period 1 while MGR did in Period 2 (Fig. 6), suggesting that a formal fire management program as has been applied in MGR during Period 2 can significantly enhance landscape heterogeneity in bush-encroached savanna within a decade.

\subsection{Fire and land use}

Burn area increased significantly only in MGR between Periods 1 and 2 (Table 5), after establishment of the MGR fire management program in 1992. Unplanned lightning ignitions on ridges probably caused most fires during Period 1, while beginning in Period 2 , areas throughout MGR with sufficient fuels were targeted for fires, which may explain the significant increase in patch shape complexity unique to MGR (Table 5). High fine fuel loads, due to substantial late-season rains, combined with severe fire weather conditions to produce an unusually active 1996 fire season in South Africa's Kruger National Park (van Wilgen et al., 2000). These same 1996 conditions produced the most active fire season in this study (Figs. 3 and 5), which may partially explain why patch size and size variability in SAF were significantly higher 
in Period 2 relative to Period 1 (Table 5). Unlike MGR and SAF, no landscape metrics changed significantly in fire-excluded BOT (Table 5), where very few fires occurred (Figs. 3-5). Viewed as a whole, the results support the second hypothesis that fire occurrence is influenced primarily by land use practice in the study area. Guyette et al. (2002) obtained similar results in the Missouri Ozarks, where the principal factor limiting fire occurrence was anthropogenic ignitions, followed by surface fuel production, fuel fragmentation and cultural behavior.

The juxtaposition of very different land use histories in the study area made it highly advantageous for comparing the effects of land use on landscape pattern over three decades. Land use zones and periods were defined in a manner commensurate with the analysis approach, but this aggregated some of the spatial and temporal variability in environmental factors existing at smaller scales. For example rainfall, which is known to greatly influence annual fire dynamics, is extremely variable within the longer-term periods defined for this study (Fig. 5). Conversely, the study periods were too short to capture larger-scale oscillations potentially driven by El Nino and La Nina events, for example. Importantly, large fires may have occurred in years for which Landsat images were unavailable, particularly the high rainfall years of the mid-1970s. Thus it must be cautioned that the narrow spatial and temporal scope of this analysis constrained the ability to capture potentially important trends due to climate variability.

\section{Conclusion}

Fire regime and vegetation patterns are related through mutual feedbacks (Whelan, 1995; Keane et al., 2002). In the South African portion of the study area where fire occurrence is higher, the patchiness of fire scars is increasing, which may indicate diversification in vegetation pattern. In the Botswanan portion of the study area where fires are excluded, vegetation pattern may be stagnant. Humans exert tremendous influence on fire regimes in semi-arid savannas and other systems (Heyerdahl et al., 2001). Strong feedbacks between fire regime and landscape composition can drive landscape change (Perry and Enright, 2002).
Global warming has sparked growing interest in the consequences of fire on vegetation (Bond, 1997). Effects of fire and grazing on vegetation pattern, and succession with respect to maintaining community diversity, are concerns of researchers, managers, and conservation planners (Turner et al., 1994; Richards et al., 1999; Fairbanks and Benn, 2000; Fairbanks et al., 2000). In conservation areas, promoting spatially and temporally variable fire regimes may be the best strategy for conserving biotic diversity (Mentis and Bailey, 1990; Kutiel, 1994). A patch-mosaic burning system may be the most effective strategy for promoting landscape heterogeneity and therefore an increase in biotic diversity (Parr and Brockett, 1999; Brockett et al., 2001).

Exceptional physical and biological diversity in southern African savannas (Scholes, 1997; Fairbanks, 2000) make this an ideal region for studying interactions between climate, fire, biota (Bond, 1997) and other natural and human factors. It is important to study these interactions at the landscape level, where spatial and temporal variability in fire and vegetation patterns can be best observed (Brockett et al., 2001; Morgan et al., 2001; Keane et al., 2002) and then used to inform land managers (Landres et al., 1999; Parr and Brockett, 1999). This requires development of spatial models (McCarthy and Cary, 2002) that explore the consequences of alternative fire regimes on vegetation pattern and process (Rupp et al., 2000a; Berjak and Hearne, 2002; Keane et al., 2002) and simulate climate stochasticity. In future research in conjunction with land managers, empirical data and spatially explicit, stochastic models will be used to explore interactions between climate, land form, vegetation, fire, herbivory and land use.

\section{Acknowledgements}

Research funding came from the NSF Biocomplexity in the Environment Program, Dynamics of Coupled Natural and Human Systems (DEB-0119827), the South African National Research Foundation, and the North West Parks and Tourism Board (NWPTB), which also purchased most of the satellite imagery used. Rainfall data were obtained from the South African Weather Service in Pretoria, the BOT Meteorological Office in Gaborone, and MGR, NWPTB. 
Rudy King, Kate Parr and two anonymous reviewers provided useful suggestions, and Ronald Robberecht assisted with graphics.

\section{Appendix A}

(1) Eigenvalues and eigenfactors of PCs 1-3 of PCAs (after varimax rotation) of the 16 landscape metrics listed in Table 2. Eigenfactors $>0.7$ (boldface) indicate metrics with heavy weight on the PC. The patch characteristic represented by each PC is interpreted for 1972-2001 trends $(\uparrow=$ increasing; $\downarrow=$ decreasing; $\uparrow \downarrow=$ variable; $\leftrightarrow=$ constant). (2) Correlation matrices among metrics. (3) Bonferroni probabilities. Results are organized by land use zone: (A) MGR; (B) SAFs; (C) BOT.

(A) (1) MGR-PCA Eigenvalues and Eigenfactors

\begin{tabular}{lccc}
\hline & $\mathrm{PC1}^{\mathrm{a}}(6.6)^{\mathrm{b}}$ & $\mathrm{PC}^{\mathrm{c}}(5.5)^{\mathrm{b}}$ & PC3 $^{\mathrm{d}}(2.8)^{\mathrm{b}}$ \\
\hline CA & 0.549 & 0.600 & 0.543 \\
LPI & $\mathbf{0 . 8 9 2}$ & 0.187 & 0.133 \\
NP & 0.076 & 0.042 & $\mathbf{0 . 9 7 7}$ \\
MPS & 0.662 & $\mathbf{0 . 7 3 2}$ & 0.100 \\
PSSD & 0.691 & 0.662 & 0.278 \\
TE & $\mathbf{0 . 7 0 3}$ & 0.175 & 0.647 \\
MSI & 0.271 & $\mathbf{0 . 9 1 4}$ & -0.059 \\
AWMSI & $\mathbf{0 . 9 0 6}$ & 0.249 & 0.148 \\
MPFD & 0.026 & $\mathbf{0 . 9 5 4}$ & 0.111 \\
AWMPFD & $\mathbf{0 . 7 9 5}$ & 0.439 & 0.169 \\
LSI & $\mathbf{0 . 7 0 3}$ & 0.175 & 0.647 \\
MPI & $\mathbf{0 . 8 2 1}$ & 0.441 & 0.302 \\
TCA & 0.559 & 0.629 & 0.511 \\
MCA & 0.614 & $\mathbf{0 . 7 3 4}$ & 0.208 \\
CASD & 0.673 & 0.652 & 0.326 \\
TCAI & 0.548 & $\mathbf{0 . 7 5 6}$ & 0.273 \\
Total variance explained & 41.6 & 34.8 & 17.7 \\
\hline
\end{tabular}

${ }^{\text {a }}$ Patch shape variability (post-1972 $\uparrow$, post- $1991 \leftrightarrow$ ).

$\mathrm{b}$ Values within parenthesis are eigenvalues.

${ }^{c}$ Shape complexity and size variability (post-1972 $\uparrow$, post-1992 $\downarrow$, post-1997 $\uparrow$ )

d Patchiness (post-1972 $\uparrow$, post $1990 \downarrow$, post $1996 \uparrow \downarrow$ ).

(2) MGR -Pearson's correlation matrix ( $\alpha<0.05$ noted in bold)

\begin{tabular}{|c|c|c|c|c|c|c|c|c|c|c|c|c|c|c|c|c|}
\hline & $\mathrm{CA}$ & LPI & NP & MPS & PSSD & $\mathrm{TE}$ & MSI & AWMSI & MPFD & AWMPFD & LSI & MPI & TCA & MCA & CASD & TCAI \\
\hline CA & 1.000 & & & & & & & & & & & & & & & \\
\hline LPI & 0.655 & 1.000 & & & & & & & & & & & & & & \\
\hline NP & 0.594 & 0.184 & 1.000 & & & & & & & & & & & & & \\
\hline MPS & 0.850 & 0.756 & 0.173 & 1.000 & & & & & & & & & & & & \\
\hline PSSD & 0.936 & 0.768 & 0.356 & 0.973 & 1.000 & & & & & & & & & & & \\
\hline TE & 0.808 & 0.787 & 0.672 & 0.667 & 0.769 & 1.000 & & & & & & & & & & \\
\hline MSI & 0.632 & 0.408 & 0.031 & 0.836 & 0.765 & 0.339 & 1.000 & & & & & & & & & \\
\hline AWMSI & 0.734 & 0.785 & 0.267 & 0.774 & 0.835 & 0.748 & 0.500 & 1.000 & & & & & & & & \\
\hline MPFD & 0.623 & 0.270 & 0.145 & 0.716 & 0.663 & 0.298 & 0.903 & 0.273 & 1.000 & & & & & & & \\
\hline AWMPFD & 0.806 & 0.704 & 0.296 & 0.836 & 0.889 & 0.710 & 0.656 & 0.969 & 0.446 & 1.000 & & & & & & \\
\hline LSI & 0.809 & 0.787 & 0.672 & 0.668 & 0.770 & 1.000 & 0.340 & 0.748 & 0.298 & 0.711 & 1.000 & & & & & \\
\hline MPI & 0.887 & 0.861 & 0.373 & 0.893 & 0.944 & 0.842 & 0.587 & 0.893 & 0.489 & 0.879 & 0.842 & 1.000 & & & & \\
\hline TCA & 0.997 & 0.666 & 0.563 & 0.878 & 0.954 & 0.805 & 0.661 & 0.742 & 0.646 & 0.813 & 0.805 & 0.897 & 1.000 & & & \\
\hline MCA & 0.902 & 0.722 & 0.263 & 0.982 & 0.976 & 0.688 & 0.781 & 0.734 & 0.708 & 0.801 & 0.688 & 0.893 & 0.927 & 1.000 & & \\
\hline CASD & 0.948 & 0.761 & 0.397 & 0.962 & 0.997 & 0.785 & 0.736 & 0.813 & 0.653 & 0.865 & 0.785 & 0.942 & 0.965 & 0.977 & 1.000 & \\
\hline TCAI & 0.904 & 0.663 & 0.323 & 0.962 & 0.967 & 0.689 & 0.778 & 0.696 & 0.732 & 0.772 & 0.690 & 0.866 & 0.932 & 0.987 & 0.973 & 1.000 \\
\hline
\end{tabular}


(3) MGR - matrix of Bonferroni probabilities (number of observations =18)

\begin{tabular}{|c|c|c|c|c|c|c|c|c|c|c|c|c|c|c|c|c|}
\hline & $\mathrm{CA}$ & LPI & NP & MPS & PSSD & $\mathrm{TE}$ & MSI & AWMSI & MPFD & AWMPFD & LSI & MPI & TCA & MCA & CASD & TCAI \\
\hline CA & 0.000 & & & & & & & & & & & & & & & \\
\hline LPI & 0.379 & 0.000 & & & & & & & & & & & & & & \\
\hline NP & 1.000 & 1.000 & 0.000 & & & & & & & & & & & & & \\
\hline MPS & 0.001 & 0.034 & 1.000 & 0.000 & & & & & & & & & & & & \\
\hline PSSD & 0.000 & 0.024 & 1.000 & 0.000 & 0.000 & & & & & & & & & & & \\
\hline TE & 0.006 & 0.013 & 0.272 & 0.297 & 0.023 & 0.000 & & & & & & & & & & \\
\hline MSI & 0.591 & 1.000 & 1.000 & 0.002 & 0.026 & 1.000 & 0.000 & & & & & & & & & \\
\hline AWMSI & 0.062 & 0.014 & 1.000 & 0.019 & 0.002 & 0.043 & 1.000 & 0.000 & & & & & & & & \\
\hline MPFD & 0.686 & 1.000 & 1.000 & 0.100 & 0.323 & 1.000 & 0.000 & 1.000 & 0.000 & & & & & & & \\
\hline AWMPFD & 0.007 & 0.132 & 1.000 & 0.002 & 0.000 & 0.115 & 0.370 & 0.000 & 1.000 & 0.000 & & & & & & \\
\hline LSI & 0.006 & 0.013 & 0.273 & 0.293 & 0.022 & 0.000 & 1.000 & 0.043 & 1.000 & 0.113 & 0.000 & & & & & \\
\hline MPI & 0.000 & 0.001 & 1.000 & 0.000 & 0.000 & 0.001 & 1.000 & 0.000 & 1.000 & 0.000 & 0.001 & 0.000 & & & & \\
\hline TCA & 0.000 & 0.307 & 1.000 & 0.000 & 0.000 & 0.007 & 0.337 & 0.051 & 0.456 & 0.005 & 0.007 & 0.000 & 0.000 & & & \\
\hline MCA & 0.000 & 0.087 & 1.000 & 0.000 & 0.000 & 0.193 & 0.016 & 0.063 & 0.121 & 0.008 & 0.191 & 0.000 & 0.000 & 0.000 & & \\
\hline CASD & 0.000 & 0.030 & 1.000 & 0.000 & 0.000 & 0.014 & 0.059 & 0.005 & 0.397 & 0.000 & 0.014 & 0.000 & 0.000 & 0.000 & 0.000 & \\
\hline TCAI & 0.000 & 0.323 & 1.000 & 0.000 & 0.000 & 0.186 & 0.017 & 0.161 & 0.066 & 0.021 & 0.184 & 0.000 & 0.000 & 0.000 & 0.000 & 0.000 \\
\hline
\end{tabular}

(B) (1) SAF-PCA Eigenvalues and Eigenfactors

\begin{tabular}{lccc}
\hline & PC1 $^{\mathrm{a}}(5.8)^{\mathrm{b}}$ & $\mathrm{PC}^{\mathrm{c}}(4.5)^{\mathrm{b}}$ & PC3 $^{\mathrm{d}}(4.1)^{\mathrm{b}}$ \\
\hline CA & 0.568 & 0.385 & 0.686 \\
LPI & $\mathbf{0 . 7 4 2}$ & 0.352 & 0.338 \\
NP & 0.134 & 0.039 & $\mathbf{0 . 9 6 4}$ \\
MPS & $\mathbf{0 . 7 9 7}$ & 0.514 & 0.160 \\
PSSD & $\mathbf{0 . 8 4 3}$ & 0.400 & 0.340 \\
TE & 0.298 & 0.294 & $\mathbf{0 . 8 6 9}$ \\
MSI & 0.180 & $\mathbf{0 . 9 0 3}$ & 0.166 \\
AWMSI & 0.420 & $\mathbf{0 . 7 3 6}$ & 0.269 \\
MPFD & 0.165 & $\mathbf{0 . 8 7 7}$ & 0.132 \\
AWMPFD & 0.391 & $\mathbf{0 . 7 9 2}$ & 0.266 \\
LSI & 0.296 & 0.295 & $\mathbf{0 . 8 6 8}$ \\
MPI & 0.544 & $\mathbf{0 . 7 1 7}$ & 0.290 \\
TCA & 0.646 & 0.359 & 0.635 \\
MCA & $\mathbf{0 . 9 3 2}$ & 0.202 & 0.186 \\
CASD & $\mathbf{0 . 7 3 6}$ & 0.383 & 0.394 \\
TCAI & $\mathbf{0 . 9 4 4}$ & 0.135 & 0.218 \\
Total variance explained & 36.4 & 27.9 & 25.5 \\
\hline
\end{tabular}

\footnotetext{
${ }^{a}$ Patch size variability (post-1972 $\downarrow$, post-1993 $\uparrow$, post-1999 $\leftrightarrow$ ).

${ }^{\mathrm{b}}$ Values within parenthesis are eigenvalues.

${ }^{\mathrm{c}}$ Shape complexity (post-1972 $\uparrow$, post-1990 $\leftrightarrow$ ).

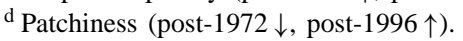


(2) SAF-Pearson's correlation matrix $(\alpha<0.05$ noted in bold)

\begin{tabular}{|c|c|c|c|c|c|c|c|c|c|c|c|c|c|c|c|c|}
\hline & $\mathrm{CA}$ & LPI & $\mathrm{NP}$ & MPS & PSSD & $\mathrm{TE}$ & MSI & AWMSI & MPFD & AWMPFD & LSI & MPI & TCA & MCA & CASD & TCAI \\
\hline $\mathrm{CA}$ & 1.000 & & & & & & & & & & & & & & & \\
\hline LPI & 0.745 & 1.000 & & & & & & & & & & & & & & \\
\hline NP & 0.776 & 0.422 & 1.000 & & & & & & & & & & & & & \\
\hline MPS & 0.745 & 0.798 & 0.248 & 1.000 & & & & & & & & & & & & \\
\hline PSSD & 0.866 & 0.872 & 0.473 & 0.924 & 1.000 & & & & & & & & & & & \\
\hline TE & 0.829 & 0.639 & 0.838 & 0.572 & 0.650 & 1.000 & & & & & & & & & & \\
\hline MSI & 0.605 & 0.422 & 0.225 & 0.679 & 0.567 & 0.454 & 1.000 & & & & & & & & & \\
\hline AWMSI & 0.656 & 0.755 & 0.327 & 0.714 & 0.748 & 0.590 & 0.643 & 1.000 & & & & & & & & \\
\hline MPFD & 0.571 & 0.398 & 0.219 & 0.607 & 0.533 & 0.392 & 0.948 & 0.581 & 1.000 & & & & & & & \\
\hline AWMPFD & 0.662 & 0.742 & 0.334 & 0.728 & 0.747 & 0.590 & 0.705 & 0.987 & 0.653 & 1.000 & & & & & & \\
\hline LSI & 0.826 & 0.638 & 0.836 & 0.571 & 0.648 & 1.000 & 0.452 & 0.593 & 0.389 & 0.593 & 1.000 & & & & & \\
\hline MPI & 0.754 & 0.788 & 0.370 & 0.822 & 0.834 & 0.641 & 0.727 & 0.892 & 0.681 & 0.914 & 0.641 & 1.000 & & & & \\
\hline TCA & 0.994 & 0.766 & 0.737 & 0.789 & 0.906 & 0.805 & 0.590 & 0.652 & 0.560 & 0.655 & 0.802 & 0.760 & 1.000 & & & \\
\hline MCA & 0.710 & 0.820 & 0.294 & 0.884 & 0.914 & 0.533 & 0.377 & 0.579 & 0.374 & 0.563 & 0.532 & 0.725 & 0.773 & 1.000 & & \\
\hline CASD & 0.914 & 0.727 & 0.537 & 0.817 & 0.925 & 0.594 & 0.611 & 0.627 & 0.570 & 0.631 & 0.591 & 0.744 & 0.937 & 0.776 & 1.000 & \\
\hline TCAI & 0.747 & 0.750 & 0.353 & 0.871 & 0.931 & 0.508 & 0.376 & 0.495 & 0.367 & 0.482 & 0.504 & 0.642 & 0.814 & 0.955 & 0.857 & 1.000 \\
\hline
\end{tabular}

(3) SAF-matrix of Bonferroni probabilities (number of observations = 21)

\begin{tabular}{|c|c|c|c|c|c|c|c|c|c|c|c|c|c|c|c|c|}
\hline & $\mathrm{CA}$ & LPI & $\mathrm{NP}$ & MPS & PSSD & $\mathrm{TE}$ & MSI & AWMSI & MPFD & AWMPFD & LSI & MPI & TCA & MCA & CASD & TCAI \\
\hline $\mathrm{CA}$ & 0.000 & & & & & & & & & & & & & & & \\
\hline LPI & 0.013 & 0.000 & & & & & & & & & & & & & & \\
\hline NP & 0.004 & 1.000 & 0.000 & & & & & & & & & & & & & \\
\hline MPS & 0.013 & 0.002 & 1.000 & 0.000 & & & & & & & & & & & & \\
\hline PSSD & 0.000 & 0.000 & 1.000 & 0.000 & 0.000 & & & & & & & & & & & \\
\hline TE & 0.000 & 0.217 & 0.000 & 0.805 & 0.171 & 0.000 & & & & & & & & & & \\
\hline MSI & 0.440 & 1.000 & 1.000 & 0.086 & 0.880 & 1.000 & 0.000 & & & & & & & & & \\
\hline AWMSI & 0.150 & 0.009 & 1.000 & 0.033 & 0.011 & 0.581 & 0.200 & 0.000 & & & & & & & & \\
\hline MPFD & 0.819 & 1.000 & 1.000 & 0.421 & 1.000 & 1.000 & 0.000 & 0.695 & 0.000 & & & & & & & \\
\hline AWMPFD & 0.128 & 0.014 & 1.000 & 0.022 & 0.012 & 0.582 & 0.044 & 0.000 & 0.160 & 0.000 & & & & & & \\
\hline LSI & 0.000 & 0.225 & 0.000 & 0.822 & 0.179 & 0.000 & 1.000 & 0.554 & 1.000 & 0.554 & 0.000 & & & & & \\
\hline MPI & 0.009 & 0.003 & 1.000 & 0.001 & 0.000 & 0.209 & 0.023 & 0.000 & 0.081 & 0.000 & 0.207 & 0.000 & & & & \\
\hline TCA & 0.000 & 0.006 & 0.016 & 0.003 & 0.000 & 0.001 & 0.586 & 0.164 & 0.994 & 0.152 & 0.001 & 0.008 & 0.000 & & & \\
\hline MCA & 0.037 & 0.001 & 1.000 & 0.000 & 0.000 & 1.000 & 1.000 & 0.711 & 1.000 & 0.938 & 1.000 & 0.024 & 0.005 & 0.000 & & \\
\hline CASD & 0.000 & 0.023 & 1.000 & 0.001 & 0.000 & 0.544 & 0.394 & 0.284 & 0.834 & 0.257 & 0.571 & 0.013 & 0.000 & 0.004 & 0.000 & \\
\hline TCAI & 0.012 & 0.011 & 1.000 & 0.000 & 0.000 & 1.000 & 1.000 & 1.000 & 1.000 & 1.000 & 1.000 & 0.206 & 0.001 & 0.000 & 0.000 & 0.000 \\
\hline
\end{tabular}

(C) (1) BOT—PCA Eigenvalues and Eigenfactors

\begin{tabular}{lcr}
\hline & $\mathrm{PC}^{\mathrm{a}}(8.6)^{\mathrm{b}}$ & $\mathrm{PC}^{\mathrm{c}}(5.8)^{\mathrm{b}}$ \\
\hline CA & $\mathbf{0 . 8 1 3}$ & 0.516 \\
LPI & $\mathbf{0 . 8 1 5}$ & 0.310 \\
NP & $\mathbf{0 . 8 7 5}$ & 0.014 \\
MPS & 0.529 & $\mathbf{0 . 8 1 4}$ \\
PSSD & $\mathbf{0 . 8 2 3}$ & 0.441 \\
TE & $\mathbf{0 . 9 1 7}$ & 0.278 \\
MSI & 0.210 & $\mathbf{0 . 9 6 4}$ \\
AWMSI & 0.638 & $\mathbf{0 . 7 0 1}$ \\
MPFD & 0.098 & $\mathbf{0 . 9 6 5}$
\end{tabular}




\begin{tabular}{lcc}
\hline & $\mathrm{PC}^{\mathrm{a}}(8.6)^{\mathrm{b}}$ & $\mathrm{PC2}^{\mathrm{c}}(5.8)^{\mathrm{b}}$ \\
\hline AWMPFD & 0.598 & $\mathbf{0 . 7 4 8}$ \\
LSI & $\mathbf{0 . 9 1 1}$ & 0.284 \\
MPI & $\mathbf{0 . 7 8 1}$ & 0.505 \\
TCA & $\mathbf{0 . 8 0 7}$ & 0.553 \\
MCA & $\mathbf{0 . 7 1 6}$ & 0.607 \\
CASD & $\mathbf{0 . 8 7 6}$ & 0.407 \\
TCAI & 0.697 & 0.635 \\
Total variance explained & 54.6 & 35.1 \\
\hline
\end{tabular}

\footnotetext{
${ }^{\text {a }}$ Patchiness and patch size variability (post-1972 $\downarrow$, post-1993 $\uparrow$, post-1999 $\leftrightarrow$ ).

${ }^{\mathrm{b}}$ Values within parenthesis are eigenvalues.

${ }^{\mathrm{c}}$ Shape complexity (post-1972 $\downarrow$, post-1996 $\uparrow$ ).
}

(2) BOT-Pearson's correlation matrix $(\alpha<0.05$ noted in bold)

\begin{tabular}{|c|c|c|c|c|c|c|c|c|c|c|c|c|c|c|c|c|}
\hline & $\mathrm{CA}$ & LPI & $\mathrm{NP}$ & MPS & PSSD & $\mathrm{TE}$ & MSI & AWMSI & MPFD & AWMPFD & LSI & MPI & TCA & MCA & CASD & TCAI \\
\hline CA & 1.000 & & & & & & & & & & & & & & & \\
\hline LPI & 0.655 & 1.000 & & & & & & & & & & & & & & \\
\hline NP & 0.594 & 0.184 & 1.000 & & & & & & & & & & & & & \\
\hline MPS & 0.850 & 0.756 & 0.173 & 1.000 & & & & & & & & & & & & \\
\hline PSSD & 0.936 & 0.768 & 0.356 & 0.973 & 1.000 & & & & & & & & & & & \\
\hline TE & 0.808 & $\mathbf{0 . 7 8 7}$ & 0.672 & 0.667 & 0.769 & 1.000 & & & & & & & & & & \\
\hline MSI & 0.632 & 0.408 & 0.031 & 0.836 & 0.765 & 0.339 & 1.000 & & & & & & & & & \\
\hline AWMSI & 0.734 & 0.785 & 0.267 & 0.774 & 0.835 & 0.748 & 0.500 & 1.000 & & & & & & & & \\
\hline MPFD & 0.623 & 0.270 & 0.145 & 0.716 & 0.663 & 0.298 & 0.903 & 0.273 & 1.000 & & & & & & & \\
\hline AWMPFD & 0.806 & 0.704 & 0.296 & 0.836 & 0.889 & 0.710 & 0.656 & 0.969 & 0.446 & 1.000 & & & & & & \\
\hline LSI & 0.809 & 0.787 & 0.672 & 0.668 & 0.770 & 1.000 & 0.340 & 0.748 & 0.298 & 0.711 & 1.000 & & & & & \\
\hline MPI & 0.887 & 0.861 & 0.373 & 0.893 & 0.944 & 0.842 & 0.587 & 0.893 & 0.489 & 0.879 & 0.842 & 1.000 & & & & \\
\hline TCA & 0.997 & 0.666 & 0.563 & 0.878 & 0.954 & 0.805 & 0.661 & 0.742 & 0.646 & 0.813 & 0.805 & 0.897 & 1.000 & & & \\
\hline MCA & 0.902 & 0.722 & 0.263 & 0.982 & 0.976 & 0.688 & 0.781 & 0.734 & 0.708 & 0.801 & 0.688 & 0.893 & 0.927 & 1.000 & & \\
\hline CASD & 0.948 & 0.761 & 0.397 & 0.962 & 0.997 & 0.785 & 0.736 & 0.813 & 0.653 & 0.865 & 0.785 & 0.942 & 0.965 & 0.977 & 1.000 & \\
\hline TCAI & 0.904 & 0.663 & 0.323 & 0.962 & 0.967 & 0.689 & 0.778 & 0.696 & 0.732 & 0.772 & 0.690 & 0.866 & 0.932 & 0.987 & 0.973 & 1.000 \\
\hline
\end{tabular}

(3) BOT-matrix of Bonferroni probabilities (number of observations =19)

\begin{tabular}{|c|c|c|c|c|c|c|c|c|c|c|c|c|c|c|c|c|}
\hline & $\mathrm{CA}$ & LPI & NP & MPS & PSSD & $\mathrm{TE}$ & MSI & AWMSI & MPFD & AWMPFD & LSI & MPI & TCA & MCA & CASD & TCAI \\
\hline CA & 0.000 & & & & & & & & & & & & & & & \\
\hline LPI & 0.052 & 0.000 & & & & & & & & & & & & & & \\
\hline NP & 0.003 & 1.000 & 0.000 & & & & & & & & & & & & & \\
\hline MPS & 0.001 & 0.036 & 1.000 & 0.000 & & & & & & & & & & & & \\
\hline PSSD & 0.000 & 0.023 & 0.093 & 0.019 & 0.000 & & & & & & & & & & & \\
\hline TE & 0.000 & 0.000 & 0.009 & 0.062 & 0.002 & 0.000 & & & & & & & & & & \\
\hline MSI & 0.207 & 1.000 & 1.000 & 0.000 & 1.000 & 1.000 & 0.000 & & & & & & & & & \\
\hline AWMSI & 0.001 & 0.032 & 1.000 & 0.000 & 0.000 & 0.006 & 0.002 & 0.000 & & & & & & & & \\
\hline MPFD & 0.786 & 1.000 & 1.000 & 0.001 & 1.000 & 1.000 & 0.000 & 0.061 & 0.000 & & & & & & & \\
\hline AWMPFD & 0.000 & 0.153 & 1.000 & 0.000 & 0.000 & 0.023 & 0.001 & 0.000 & 0.012 & 0.000 & & & & & & \\
\hline LSI & 0.001 & 0.000 & 0.013 & 0.057 & 0.003 & 0.000 & 1.000 & 0.005 & 1.000 & 0.022 & 0.000 & & & & & \\
\hline MPI & 0.000 & 0.003 & 0.587 & 0.005 & 0.000 & 0.001 & 0.330 & 0.000 & 1.000 & 0.000 & 0.001 & 0.000 & & & & \\
\hline TCA & 0.000 & 0.017 & 0.014 & 0.000 & 0.000 & 0.000 & 0.105 & 0.000 & 0.596 & 0.000 & 0.000 & 0.000 & 0.000 & & & \\
\hline MCA & 0.000 & 0.024 & 0.289 & 0.000 & 0.002 & 0.009 & 0.067 & 0.003 & 0.434 & 0.001 & 0.010 & 0.007 & 0.000 & 0.000 & & \\
\hline CASD & 0.000 & 0.004 & 0.029 & 0.009 & 0.000 & 0.000 & 1.000 & 0.001 & 1.000 & 0.002 & 0.000 & 0.000 & 0.000 & 0.000 & 0.000 & \\
\hline TCAI & 0.000 & 0.007 & 0.951 & 0.000 & 0.004 & 0.007 & 0.041 & 0.001 & 0.346 & 0.001 & 0.007 & 0.003 & 0.000 & 0.000 & 0.000 & 0.000 \\
\hline
\end{tabular}




\section{References}

Acocks, J.P.H., 1953. Veld types of South Africa. Mem. Bot. Surv. South Africa 28, 1-128.

Baker, W.L., 1992. Effects of settlement and fire suppression on landscape structure. Ecology 73, 1879-1887.

Baker, W.L., 1994. Restoration of landscape structure altered by fire suppression. Conserv. Biol. 8, 763-769.

Berjak, S.G., Hearne, J.W., 2002. An improved cellular automaton model for simulating fire in a spatially heterogeneous savanna system. Ecol. Model. 148, 133-151.

Bond, W.J., 1997. Fire. In: Cowling, R.M., Richardson, D.M., Pierce, S.M. (Eds.), Vegetation of Southern Africa. Cambridge University Press, Cambridge, pp. 421-446.

Bond, W.J., van Wilgen, B.W., 1996. Fire and Plants. Chapman \& Hall, London.

Brockett, B.H., Biggs, H.C., van Wilgen, B.W., 2001. A patch mosaic burning system for conservation areas in southern African savannas. Int. J. Wildland Fire 10, 169-183.

Christensen, N.L., 1981. Fire regimes in southeastern ecosystems. In: Proceedings of the Conference on Fire Regimes and Ecosystem Properties, December 11-15, 1978. US Department of Agriculture General Technical Report No. WO-26, pp. 112-136.

Fairbanks, D.H.K., 2000. Physio-climatic classification of South Africa's woodland biome. Plant Ecol. 149, 71-89.

Fairbanks, D.H.K., Benn, G.A., 2000. Identifying regional landscapes for conservation planning: a case study from KwaZulu-Natal, South Africa. Landscape Urban Plan. 50, $237-$ 257.

Fairbanks, D.H.K., Thompson, M.W., Vink, D.E., Newby, T.S., van den Berg, H.M., Everard, D.A., 2000. The South African land-cover characteristics database: a synopsis of the landscape. S. Afr. J. Sci. 96, 69-82.

Forman, R.T.T., 1995. Land Mosaics. The Ecology of Landscapes and Regions. Cambridge University Press, New York, pp. 351-363.

Fung, T., LeDrew, E., 1987. Application of principal components analysis to change detection. Photogramm. Eng. Remote Sens. 53, 1649-1658.

Gill, A.M., Ryan, P.G., Moore, P.H.R., Gibson, M., 2000. Fire regimes of World Heritage Kakadu National Park, Australia. Aust. Ecol. 25, 616-625.

Gustafson, E.J., 1998. Quantifying landscape spatial pattern: what is the state of the art? Ecosystems 1, 143-156.

Guyette, R.P., Muzika, R.M., Dey, D.C., 2002. Dynamics of an anthropogenic fire regime. Ecosystems 5, 472-486.

Haydon, D.T., Friar, J.K., Pianka, E.R., 2000. Fire-driven dynamic mosaics in the Great Victoria Desert, Australia. Landscape Ecol. 15, 373-381.

Henry, M.C., Yool, S.R., 2002. Characterizing fire-related spatial patterns in the Arizona Sky Islands using Landsat TM data. Photogramm. Eng. Remote Sens. 68, 1011-1019.

Heyerdahl, E.K., Brubaker, L.B., Agee, J.K., 2001. Spatial controls of historical fire regimes: a multiscale example from the Interior West USA. Ecology 82, 660-678.
Hudak, A.T., 1999a. Ecological causes and effects of bush encroachment in South African savanna. Ph.D. Thesis. University of Colorado, Boulder, CO.

Hudak, A.T., 1999b. Rangeland mismanagement in South Africa: failure to apply ecological knowledge. Human Ecol. 27, 55-78.

Hudak, A.T., Brockett, B.H., 2004. Mapping fire scars in a southern African savanna using Landsat imagery. Int. J. Remote Sens., in press.

Hudak, A.T., Brockett, B.H., Wessman, C.A., 1998. Fire scar mapping in a southern African savanna. In: Proceedings of the International Geoscience and Remote Sensing Symposium, Seattle, WA.

Hudak, A.T., Seastedt, T.R., Wessman, C.A., 2003. Woody overstorey effects on soil carbon and nitrogen pools in South African savanna. Aust. Ecol. 28, 173-181.

Jackson, D.A., 1993. Stopping rules in principal components analysis: a comparison of heuristical and statistical approaches. Ecology 74, 2204-2214.

Keane, R.E., Parsons, R.A., Hessburg, P.F., 2002. Estimating historical range and variation of landscape patch dynamics: limitations of the simulation approach. Ecol. Model. 151, 2949.

Kilgore, B.M., 1981. Fire in ecosystem distribution and structure: western forests and scrublands. In: Proceedings of the Conference on Fire Regimes and Ecosystem Properties, December 11-15, 1978. US Department of Agriculture General Technical Report No. WO-26, pp. 58-89.

Kutiel, K., 1994. Fire and ecosystem heterogeneity: a Mediterranean case study. Earth Surf. Proc. Land. 19, 187-194.

Landres, P.B., Morgan, P., Swanson, F.J., 1999. Overview of the use of natural variability concepts in managing ecological systems. Ecol. Appl. 9, 1179-1188.

Legendre, P., Legendre, L., 1998. Numerical Ecology, 2nd English Edition. Elsevier, Amsterdam.

Leitao, A.B., Ahern, J., 2002. Applying landscape ecological concepts and metrics in sustainable landscape planning. Landscape Urban Plan. 59, 65-93.

McCarthy, M.A., Cary, G.J., 2002. Fire regimes in landscapes: models and realities. In: Flammable Australia. The Fire Regimes and Biodiversity of a Continent. Cambridge University Press, Cambridge.

McGarigal, K., Marks, B.J., 1995. FRAGSTATS: spatial pattern analysis program for quantifying landscape structure. US Forest Service General Technical Report No. PNW 351.

McGarigal, K., McComb, W.C., 1995. Relationships between landscape structure and breeding birds in the Oregon coast range. Ecol. Monogr. 65, 235-260.

McNaughton, S.J., 1984. Grazing lawns: animals in herds, plant form, and coevolution. Am. Nat. 124, 863-886.

Mentis, M.T., Bailey, A.W., 1990. Changing perceptions of fire management in savanna parks. J. Grassland Soc. S. Afr. 7, 8185.

Morgan, P., Hardy, C.C., Swetnam, T.W., Rollins, M.G., Long, D.G., 2001. Mapping fire regimes across time and space: understanding coarse and fine scale patterns. Int. J. Wildland Fire 10, 329-342.

Norton-Griffiths, M., 1979. The influence of grazing, browsing and fire on the vegetation dynamics of the Serengeti. In: Sinclair, 
A.R.E., Norton-Griffiths, M. (Eds.), Serengeti: Dynamics of an Ecosystem. University of Chicago Press, Chicago, IL, pp. 310-352.

O’Neill, R.V., Hunsaker, C.T., Timmins, S.P., Jackson, B.L., Jones, K.B., Riitters, K.H., Wickham, J.D., 1996. Scale problems in reporting landscape pattern at the regional scale. Landscape Ecol. 11, 169-180.

Parr, C.L., Brockett, B.H., 1999. Patch-mosaic burning: a new paradigm for savanna fire management in protected areas? Koedoe 42, 117-130.

Patterson, M.W., Yool, S.R., 1998. Mapping fire-induced vegetation mortality using Landsat Thematic Mapper data: a comparison of linear transformation techniques. Remote Sens. Environ. 65, $132-142$.

Perry, G.L.W., Enright, N.J., 2002. Humans, fire and landscape pattern: understanding a maquis-forest complex, Mont Do, New Caledonia, using a spatial 'state-and-transition' model. J. Biogeogr. 29, 1143-1158.

Phillips, J.F.V., 1930. Fire: its influence on biotic communities and physical factors in South and East Africa. S. Afr. J. Sci. 27, 352-367.

Riba, M., Terradas, J., 1987. Characteristiques de la resposta als incendis en els ecosistemes mediterranis. In: Terredas, J. (Ed.), Ecosistemes Terrestres. Diputacio de Bercelona, Spain, pp. 63-75.

Richards, J.A., 1984. Thematic mapping from multitemporal image data using the principal components transformation. Remote Sens. Environ. 16, 35-46.

Richards, S.A., Possingham, H.P., Tizard, J., 1999. Optimal fire management for maintaining community diversity. Ecol. Appl. 9, 880-892.

Riitters, K.H., O’Neill, R.V., Hunsaker, C.T., Yankee, D.H., Timmins, S.P., Jones, R.B., Jackson, B.L., 1995. A factor analysis of landscape pattern and structure metrics. Landscape Ecol. 10, 23-39.

Rupp, T.S., Chapin III, F.S., Starfield, A.M., 2000a. Response of subarctic vegetation to transient climatic change on the Seward Peninsula in northwest Alaska. Glob. Change Biol. 6, 541555.

Rupp, T.S., Starfield, A.M., Chapin III, F.S., 2000b. A frame-based spatially explicit model of subarctic vegetation response to climatic change: comparison with a point model. Landscape Ecol. 15, 383-400.

Russell-Smith, J., Ryan, P.G., Durieu, R., 1997. A Landsat MSS-derived fire history of Kakadu National Park, monsoonal northern Australia, 1980-94: seasonal extent, frequency and patchiness. J. Appl. Ecol. 34, 748-766.
Rutherford, M.C., 1980. Annual plant-production-precipitation relations in arid and semi-arid regions. S. Afr. J. Sci. 76, 53-56.

Scholes, R.J., 1997. Savanna. In: Cowling, R.M., Richardson, D.M., Pierce, S.M. (Eds.), Vegetation of Southern Africa. Cambridge University Press, Cambridge, pp. 258-277.

Scholes, R.J., Walker, B.H., 1993. An African Savanna. Synthesis of the Nylsvley Study. Cambridge University Press, Cambridge.

Setplan, 1991. Dwarsberg: a development assessment. Report Commissioned by Agricor. Settlement Planning Associates, 37 pp.

Singh, A., Harrison, A., 1985. Standardized principal components. Int. J. Remote Sens. 6, 883-896.

Smit, G.N., 1990. Kouebeskadiging van houtagtige plante in die Suuragtige-Gemengde Bosveld. Tydskrif Weidingsveren S. Afr. 7, 196-200.

Tinker, D.B., Resor, C.A.C., Beauvais, G.P., Kipfmueller, K.F., Fernandes, C.I., Baker, W.L., 1998. Watershed analysis of forest fragmentation by clearcuts and roads in a Wyoming forest. Landscape Ecol. 13, 149-165.

Trapnell, C.G., 1959. Ecological results of woodland burning experiments in northern Rhodesia. J. Ecol. 47, 129-168.

Trollope, W.S.W., 1984. Fire in savanna. In: de Booysen, P.V., Tainton, N.M. (Eds.), Ecological Effects of Fire in South African Ecosystems. Springer, Berlin, pp. 149-176.

Trollope, W.S.W., Tainton, N.M., 1986. Effect of fire intensity on the grass and bush components of the eastern Cape thornveld. J. Grassland Soc. S. Afr. 3, 37-42.

Turner, M.G., Hargrove, W.W., Gardner, R.H., Romme, W.H., 1994. Effects of fire on landscape heterogeneity in Yellowstone National Park, Wyoming. J. Veg. Sci. 5, 731-742.

van Wilgen, B.W., Everson, C.S., Trollope, W.S.W., 1990. Fire management in southern Africa: some examples of current objectives, practices and problems. In: Goldammer, J.G. (Ed.), Fire in the Tropical Biota: Ecosystem Processes and Global Challenges. Springer, Berlin, pp. 179-215.

van Wilgen, B.W., Biggs, H.C., O'Regan, S.P., Mare, N., 2000. A fire history of the savanna ecosystems in the Kruger National Park, South Africa, between 1941 and 1996. S. Afr. J. Sci. 96, 167-178.

Westoby, M., Walker, B.H., Noy-Meir, I., 1989. Opportunistic management for rangelands not at equilibrium. J. Range Manage. 42, 266-274.

Whelan, R.J., 1995. The Ecology of Fire. Cambridge University Press, Cambridge, pp. 8-9.

White, J.D., Ryan, K.C., Key, C.C., Running, S.W., 1996. Remote sensing of forest fire severity and vegetation recovery. Int. J. Wildland Fire 6, 125-136. 